\title{
Temperature of Paved Streets in Urban Mockups and Its Implication of Reflective Cool Pavements
}

\author{
Yi Zhang ${ }^{1}$, Peiyuan Wei ${ }^{2}$, Lei Wang ${ }^{1}$ and Yinghong Qin ${ }^{1,2, *}$ \\ 1 College of Civil Engineering and Architecture, Guilin University of Technology, Guilin 541004, China; \\ yzhang@glut.edu.cn (Y.Z.); lwang@glut.edu.cn (L.W.) \\ 2 College of Civil Engineering and Architecture, Guangxi University, 100 University Road, \\ Nanning 530004, China; peiyuanwei@st.gxu.edu.cn \\ * Correspondence: yqin1@mtu.edu; Tel.: +86-771-323-2464
}

Citation: Zhang, Y.; Wei, P.; Wang, L.; Qin, Y. Temperature of Paved Streets in Urban Mockups and Its Implication of Reflective Cool Pavements. Atmosphere 2021, 12, 560. https://doi.org/10.3390/ atmos12050560

Academic Editors

Hideki Takebayashi and Jihui Yuan

Received: 31 March 2021

Accepted: 21 April 2021

Published: 26 April 2021

Publisher's Note: MDPI stays neutral with regard to jurisdictional claims in published maps and institutional affiliations.

Copyright: (c) 2021 by the authors. Licensee MDPI, Basel, Switzerland. This article is an open access article distributed under the terms and conditions of the Creative Commons Attribution (CC BY) license (https:// creativecommons.org/licenses/by/ $4.0 /)$.

\begin{abstract}
In summer, urban heat islands increase building cooling demands, aggravate air pollution, and cause heat-related illnesses. As a mitigation strategy, reflective cool pavements have been deemed an effective measure to decrease the temperature in urban areas. However, the reflection of paved streets in an urban area will be different from that in an open area. It remains unknown which fraction of paved streets needs to be cooled upmost, and if increasing the albedo of paved streets can effectively reduce their temperature. This study measured the skin temperature of two urban mockups, of which one contained white streets and the other, gray streets. The streets were orientated at different strikes. It was found that in summer the East-West street was hotter than both the cross street and the South-North street. At nighttime, the heat released from building blocks kept the paved street about $0.2{ }^{\circ} \mathrm{C}$ hotter than paved areas in open spaces. It was also found that street orientation controlled the skin temperature of an urban street while the sky view factor (or building height and street width) acted in a secondary role only. Increasing the albedo of the paved street in an urban canyon effectively reduced the skin temperature of the street. Reflective pavements should be built preferentially on East-West streets and the cross streets.
\end{abstract}

Keywords: urban street; temperature; thermal comfort; sky view factor; cool pavements; street orientation

\section{Introduction}

Urbanization alters the thermal environment from its natural conditions by replacing natural evaporable soils and green coverings with paved streets and building blocks. Both the buildings and the streets create a space that is similar to a canyon, which is termed an urban canyon. Solar irradiance to an urban canyon is entirely different from solar irradiance on natural ground in an open space. Photons reflected from paved streets can be captured by the adjacent buildings [1-4]. Heat absorbed by the urban street cannot discharge as it does in rural area because the radiant heat re-radiates between buildings and because the sensible heat is retained in the canyon due to the reduction of air flow [5]. As a consequence, cities experience elevated air temperature, a phenomenon that is termed an urban heat island. The urban heat island effect directly reduces the thermal comfort of the cities' residences [6-10], reduces the urban environmental quality [11-13], increases the urban energy usage [14,15], and causes other heat-related health problems [16-18].

As paved surfaces make up $20-40 \%$ of urban texture, the implementation of cool pavements as a strategy for mitigating the urban heat island effect has recently gained momentum [19-22]. Reflective pavement is a type of "cool pavement" that can reflect more sunlight than convectional pavements. Due to this feature, reflective pavements are expected to be built in places that have long isolation time, and that are exposed to strong solar irradiance. As the solar irradiance to an urban street is different from that to a paved surface in open area, whether a reflective pavement in an urban canyon can effectively 
reduce the skin temperature remains unknown. By studying the shady area of an urban space, Takebayashi et al. [23] found that reflective cool pavements should be considered on the north sides of East-West streets and the centers of North-South streets. It was also found that the thermal comfort of an urban canyon is jointly influenced by the sky view factor, the ratio of building height and street width, and the street orientation [24-27]. While the skin temperature of an urban area has been widely modelled, the skin temperature of an urban street is seldom measured, which is important to precisely decide which fraction of urban texture needs reflective pavements most.

This study measures the skin temperature of two square urban mockups to understand the temperature of paved streets. Gray concrete cubes were placed on a flat paved surface to represent the building blocks in an urban area. The paved surface under the cubic blocks was set as a gray substrate and a white substrate, respectively, for representing a gray paved street and a white one. Adjacent to the square mockups, a gray paved square and a white paved one were prepared to compare the paved skin temperature in a paved street to a paved surface in open area. The skin temperature of the two mockups and the two open squares were measured simultaneously on typical summer days to conclude whether reflective pavements in urban area can effectively decrease the skin temperature of paved streets.

\section{Experiments}

Typically, an urban canyon consists of building blocks and urban streets. To make the street high-reflective, we painted a $2.2 \mathrm{~m} \times 2.2 \mathrm{~m}$ square on the flat roof white. After the paint hardened, concrete cubes with an edge length of $0.15 \mathrm{~m}$ were arranged on the white square such that the space between two adjacent blocks was set as $0.15 \mathrm{~m}$. In this setup, the cubes represented the building blocks and the area uncovered by the cubes stood for high-reflective paved streets. Considering that urban buildings are usually gray, we painted the hardened concrete cubes gray before placing them on the white square. At $1.5 \mathrm{~m}$ from the white square, a new square area was painted gray with the same color as the paint on the concrete cubes. Upon the gray square, the same type of concrete cubes were placed in order to mimic the urban area with a gray street. The morphology of the two urban mockups was exactly the same. Parallel with the urban mockup with the white paved street, another white square with the same length was painted to mimic a high-reflective pavement in an open area. Similarly, parallel with the gray urban mockup, a new gray open square with the same length was prepared. The geometry of the four urban squares can be seen in Figure 1.

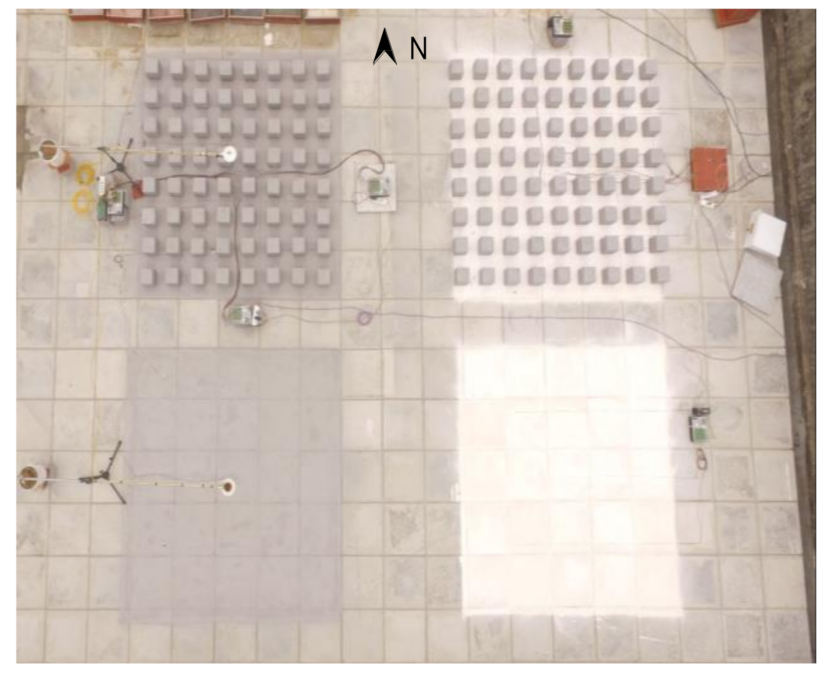

Figure 1. Two urban mockups and two open squares with the same size side-by-side for determining the temperature difference between pavements in urban areas and in open areas. 
The solar reflectance spectrum of the white paint and of the gray paint on concrete surfaces was tested using a Lambda 900 with an integral sphere. Each paint was sprayed onto six hardened concrete slices. Weighing the solar reflectance with the spectrum of air-mass on global horizontal solar irradiance, it was found that the albedo of the white paint was $0.55+0.03$ and of the gray paint was $0.30+0.02$, see Appendix A. To get the temperature of the paved street in an urban area, thermocouples were anchored to the paved street on the urban mockup to measure the local temperature. Considering the thermal symmetry of the mockup, temperatures of the East-West street, South-North street and cross street were measured. In addition, the skin temperature at the centers of the white open square and of the gray open square were measured simultaneously. To get the true temperature, the thermocouple was mounted on a copper plate, which was then anchored to the designed place. The plates, thermocouple tips, and lines were then painted unicolor to minimize the thermal disturbance caused by the measurement. Thermocouples were deployed as indicated in the Figure 2.

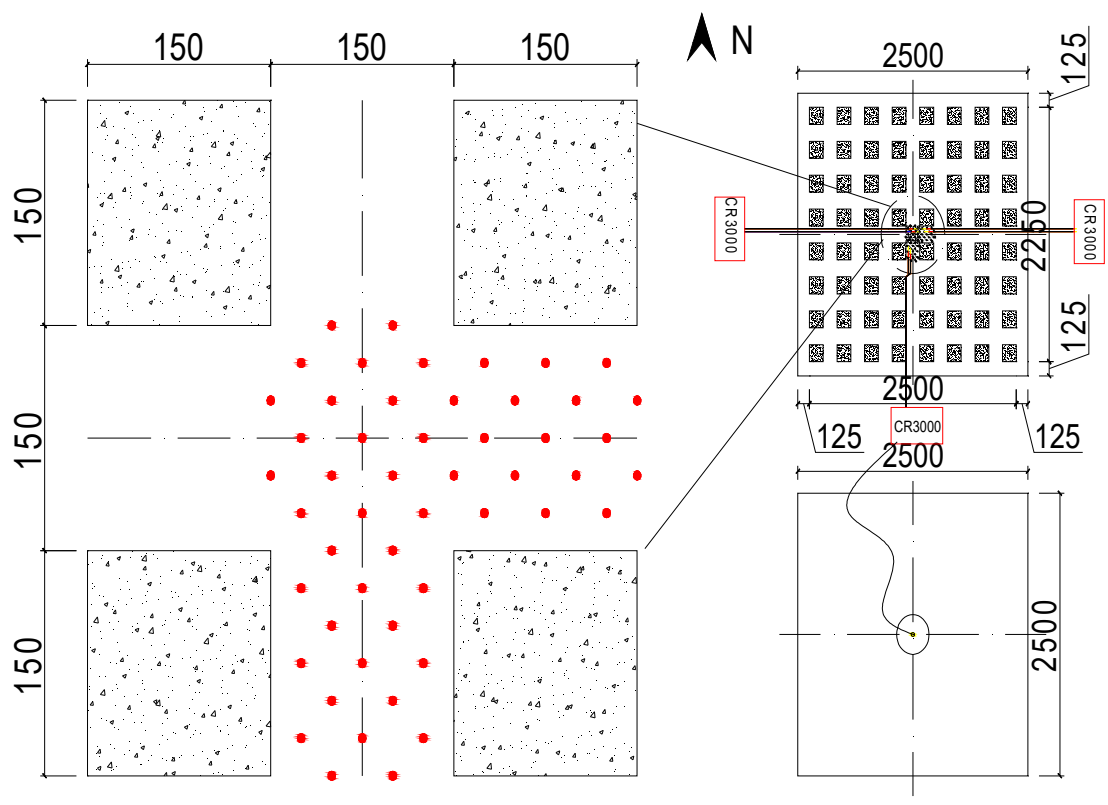

Figure 2. Schematic show of thermocouples that were installed to log the temperature of places in the urban mockup with gray streets. While the thermocouples did not cover the entire street in the representative area, the temperature of the entire street can be extrapolated due to the thermal symmetry of the streets.

The experiment was conducted on the rooftop of a building in Guangxi University, China (latitude, 22.84 and longitude 108.29). The temperature data were logged by three Campbell CR3000s simultaneously at an interval of $60 \mathrm{~s}$. The experiment began from 19 June 2018 to 24 June 2019 , a period that was partially sunny.

\section{Results}

\subsection{Skin Temperatures of an Urban Street}

The skin temperatures at different places in the gray streets were different by less than $2{ }^{\circ} \mathrm{C}$ at solar noon (Figure 3). As indicated in Figure 3, the temperature contour was different place to place, but a closer look found that the highest temperature was approximately $49^{\circ} \mathrm{C}$, while the lowest temperature was close to $47^{\circ} \mathrm{C}$. The maximum difference was about $2{ }^{\circ} \mathrm{C}$. As a result, there are some small difference at temperature contours across the street, possibly because of the measurement error of the thermocouple sensors. The small difference in the skin temperature is because at solar noon, the sun is right above the urban street so the solar irradiance on the street is similar. While the 
temperature difference is small, one can find that the East-West street is hotter than both the cross street and the South-North street.

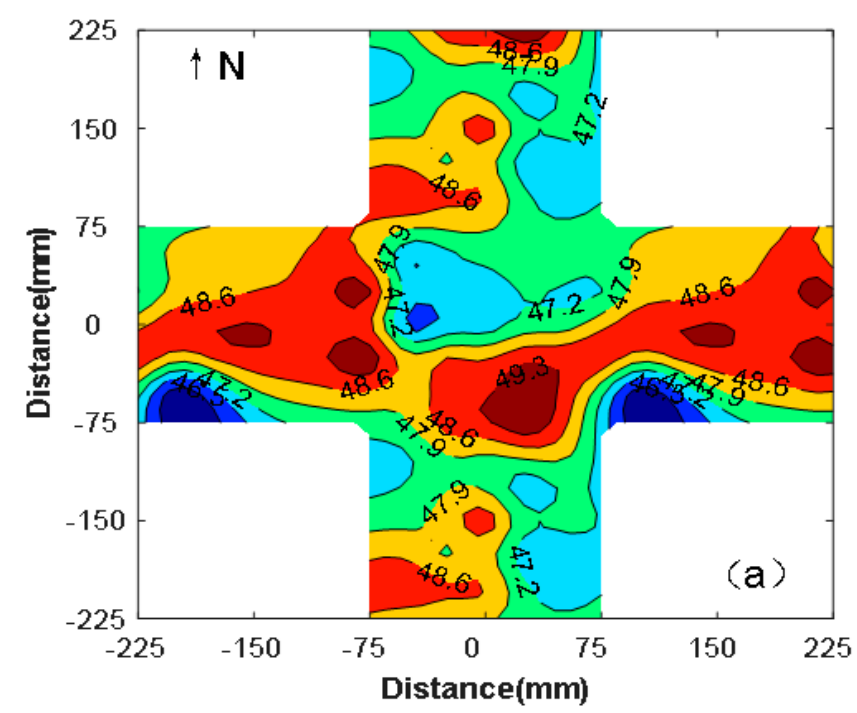

Figure 3. Skin temperature of the typical gray street of the mockup at the solar noon on 21 June.

The skin temperature of the gray street told a different story at 15:00 (Figure 4). At this time, the skin temperature of the urban street peaked because the surface temperature of an un-evaporable surface usually peaks three hours behind the solar noon [28]. At 15:00, the sun stays at the West; as a result, the West side of the urban street is shaded by the blocks and thus is the coolest place across the street. At this time, the cross street and the East-West street is still insolated by the sun and thus is still hot. The difference of the skin temperature in this study was magnified, with a maximum temperature approaching $49^{\circ} \mathrm{C}$ and a minimum close to $43^{\circ} \mathrm{C}$. This different temperature and temperature contour infers that during daytime, the most effective way to reduce the skin temperature of an urban street is to increase the shady area.

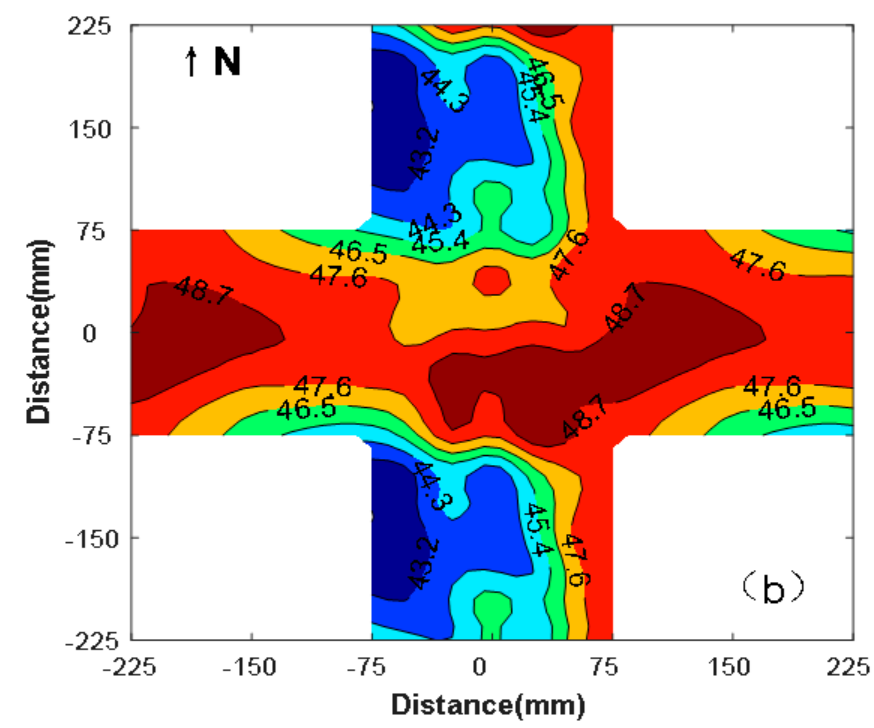

Figure 4. Skin temperature of the typical gray street of the mockup at 15:00 on 21 June.

The skin temperature of the gray street at 24:00 was different from that at other times (Figure 5). The magnitude of the difference of the skin temperature at different places decreased to a range of $0-1.0^{\circ} \mathrm{C}$. At this time, the cross street was the coolest place because the sky view factor of the cross street was greatest compared to that of both the East-West 
street and South-North street. The influence of the sky view factor on the skin temperature of the paved street could be seen from the skin temperature of the place that was closest to the building wall, which was $0.1-0.3{ }^{\circ} \mathrm{C}$ hotter than the skin temperature at the middle of the street. Similarly, the East-West street was about $0.1-0.2{ }^{\circ} \mathrm{C}$ cooler than that the South-North one. This difference was due to a marginal measurement error. The difference may also be because turbulence convection at the measurement time was different. This experiment reveals that the sky view factor has a limited effect on the skin temperature of paved streets.

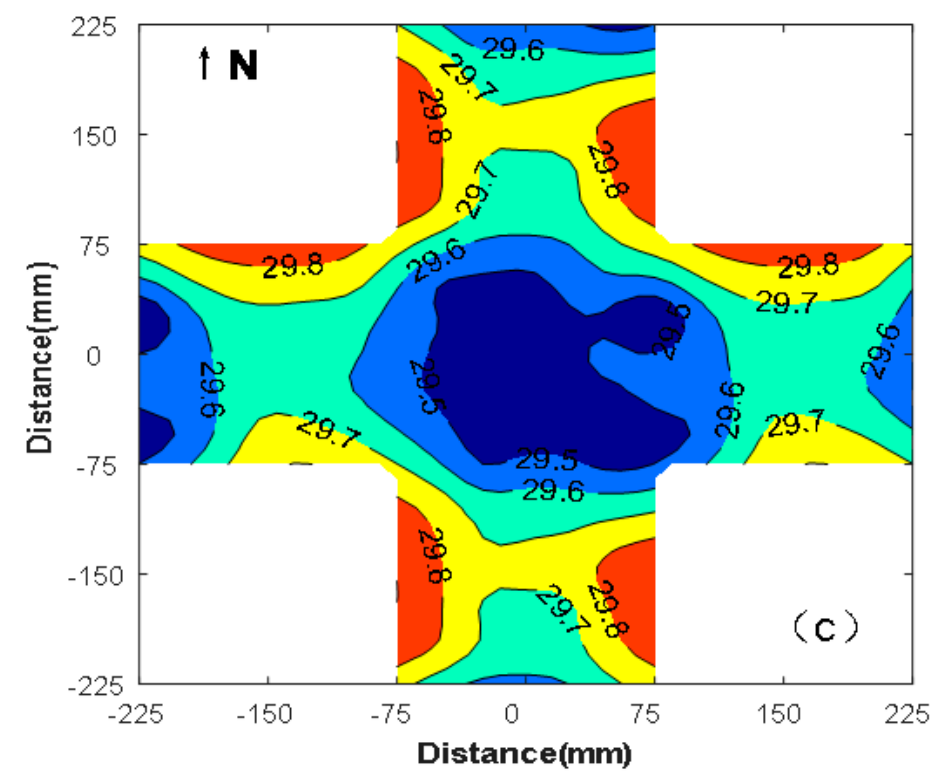

Figure 5. Skin temperature of the typical gray street of the mockup at 24:00 on 21 June.

The mean daily skin temperature across the street on 21 June is shown in Figure 6. It was found that the South-North street was the coolest place on the urban street. This is reasonable, because some parts of the South-North street were shaded, except for at the solar noon. This further substantiates that increasing the shady area is the most effective strategy for reducing the temperature of urban streets. The hottest place was the East-West street. The reason for this was that the East-West street received greater solar irradiance than the South-North street, but had a lower sky view factor than the cross street. The hottest place on the East-West street was the middle of the street for the reason that the places closer to the building blocks were shaded for some time due to the variation of the solar position during the course of the day. The cross street had the greatest sky view factor to dissipate heat at nighttime, but it received the greatest solar irradiance at daytime; the mean daily temperature of the cross street was thus somewhere between that of the South-North and East-West street.

It is a surprise that the East side of a South-North street was cooler than the West side. This thermal asymmetry may be caused by the different solar irradiance during the measured day, at which the solar irradiance at the afternoon is smaller than that at the morning. To better understand the cause for this thermal asymmetry, the mean skin temperature of the urban street during four continual measured days are plotted in Figure 7. It was found that the four-day mean skin temperature of the street, in pattern and in distribution, was highly similar to the mean skin temperature of the street on 21 June. This similar temperature contour further confirms the phenomenon that the East site of the South-North street was cooler than the West site. The difference was $0.3-0.6{ }^{\circ} \mathrm{C}$, but the reason behind this difference needs further study. 


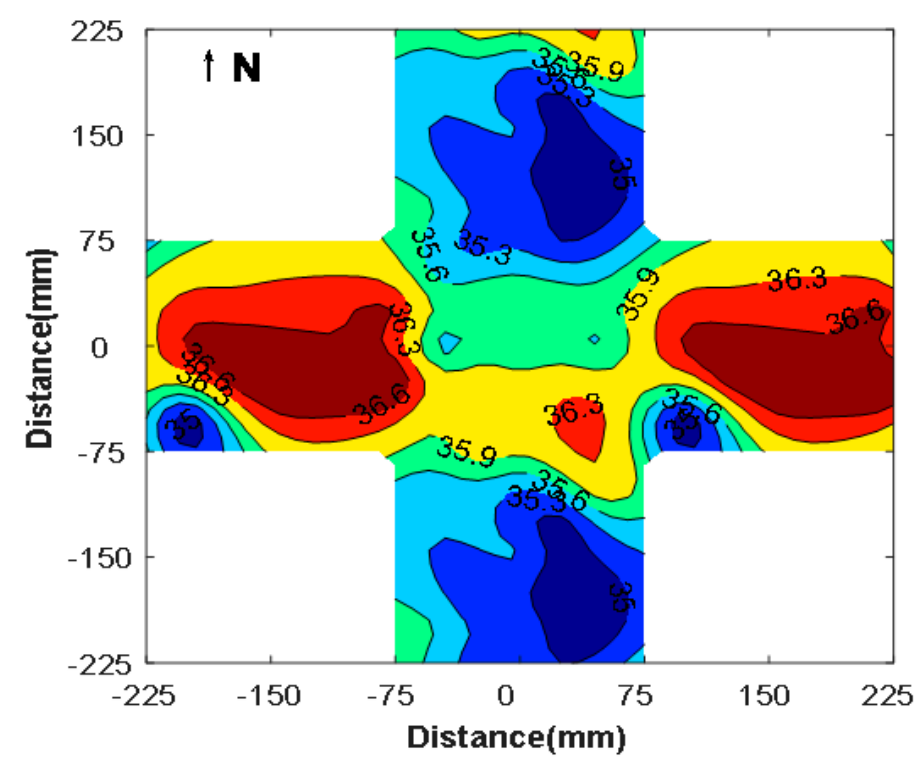

Figure 6. Mean daily skin temperature of typical gray streets of the urban mockup on 21 June 2019.

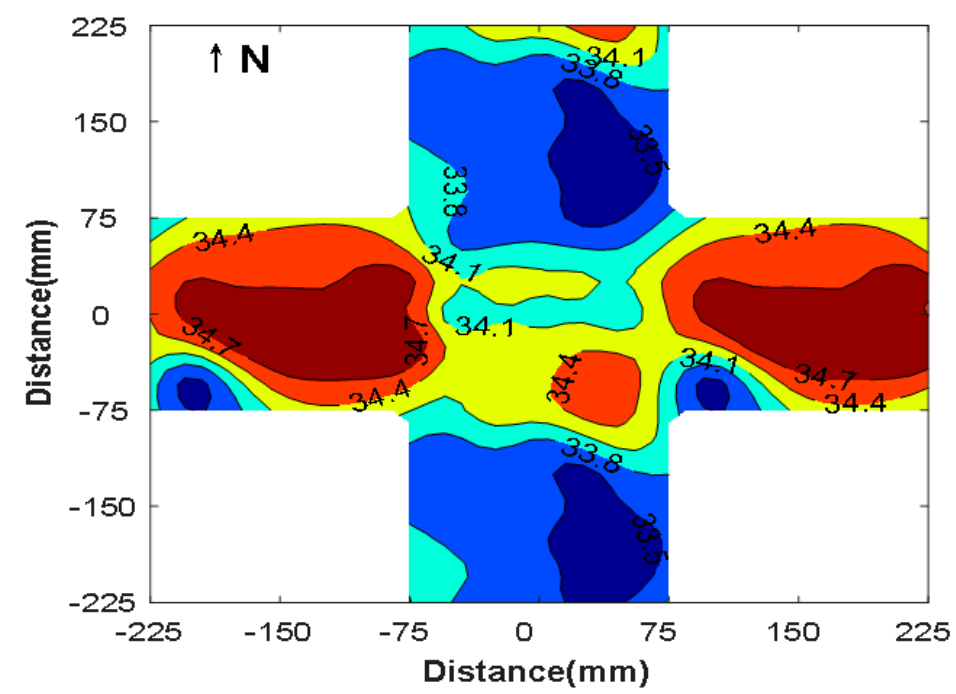

Figure 7. Four-day mean skin temperature of the typical paved street in the urban street mockup from 19-23 June 2019.

\subsection{Reducing Skin Temperature by Increasing the Street Albedo}

It is well-known that increasing the albedo of a paved area in an open space reduces the skin temperature effectively. The temperature reduction is compromised somewhat when the paved area in an urban area is made high-reflective. This study measures temperatures at the centers of a gray urban mockup, of a white urban mockup, of a gray open square, and of a white open square simultaneously. As shown in Figure 8, the center of the gray urban mockup was $5-10^{\circ} \mathrm{C}$ cooler than that of the gray open square. This difference is reasonable, because compared to the gray streets at the center of an urban area, the center of the gray open square receives more sunlight and is exposed to longer isolation. It is interesting that at daytime, the temperature at the center of the white urban mockup was almost equal to the temperature at the center of the white open square. This equality of temperature means that if the urban street was made high-reflective, the solar trapping effect of an urban area would play a secondary role in the skin temperature variation. Another interesting result in Figure 8 is that at nighttime, the paved areas in the open squares were always about $1-2{ }^{\circ} \mathrm{C}$ cooler than those in the urban mockup. One reason for this difference is that concrete cubes reduce the sky view of the paved areas in the urban canyon. Another reason is that in the 
urban mockup, the heat emitted from the concrete cubes was absorbed by the paved area, making the paved area in the urban canyon hotter.

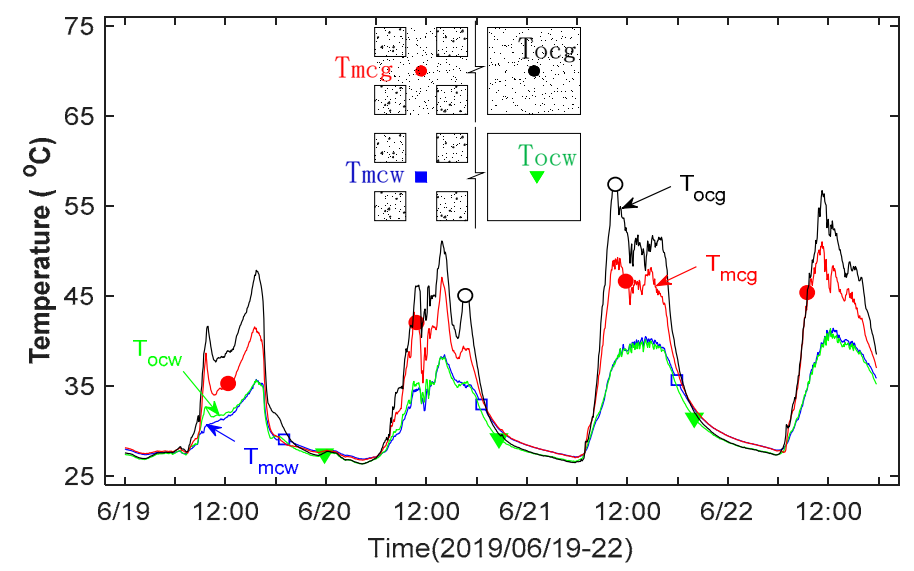

Figure 8. Daily temperature series at the center of the gray unban mockup, of the white urban mockup, of the gray open square and of the white open square. Noted: subscripts o = open square, $\mathrm{m}=$ mockup, $\mathrm{c}=$ center, $\mathrm{g}=$ gray, and $\mathrm{w}=$ white

Due to the shading effect of the urban canyon, the reflective paved street in the urban mockup could not be cooled in the same way as those pavements in an open area. To estimate this difference, Figure 9 compares the time serials of $T_{\text {ocg }}-T_{o c w}$ and $T_{m c g}-T_{m c w}$ (subscripts $\mathrm{o}=$ open square, $\mathrm{c}=$ center, $\mathrm{g}=$ gray, and $\mathrm{w}=$ white). It was found that making the pavement high-reflective reduces the skin temperature up to $20^{\circ} \mathrm{C}$ in an open area and up to $10^{\circ} \mathrm{C}$ in an urban canyon, substantiating the claim that increasing the pavement in an urban area effectively cools the pavement. At nighttime, the influence of albedo on the skin temperature of paved streets vanishes. To further demonstrate this effectiveness, the ratio $\delta=\left(\mathrm{T}_{\mathrm{mcg}}-\mathrm{T}_{\mathrm{miw}}\right) /\left(\mathrm{T}_{\mathrm{ocg}}-\mathrm{T}_{\mathrm{ocw}}\right)$ was calculated to illustrate the effect of using reflective streets in urban areas. The value of $\delta$ was set from 0 to 1.0, with 0 for full discount and 1.0 for no discount. It was found that $\delta$ varied somewhere between 0 and 1.0. The average of $\delta$ was 0.786 ; the discount was 0.214 . That is, if increasing the albedo of a paved surface in an open area decreases the skin temperature by $10^{\circ} \mathrm{C}$, the same albedo increment for a paved street in an urban area would be $7.86^{\circ} \mathrm{C}$. One can conclude that increasing the albedo of paved streets effectively reduces the skin temperature of the street in an urban morphology such as the mockup.
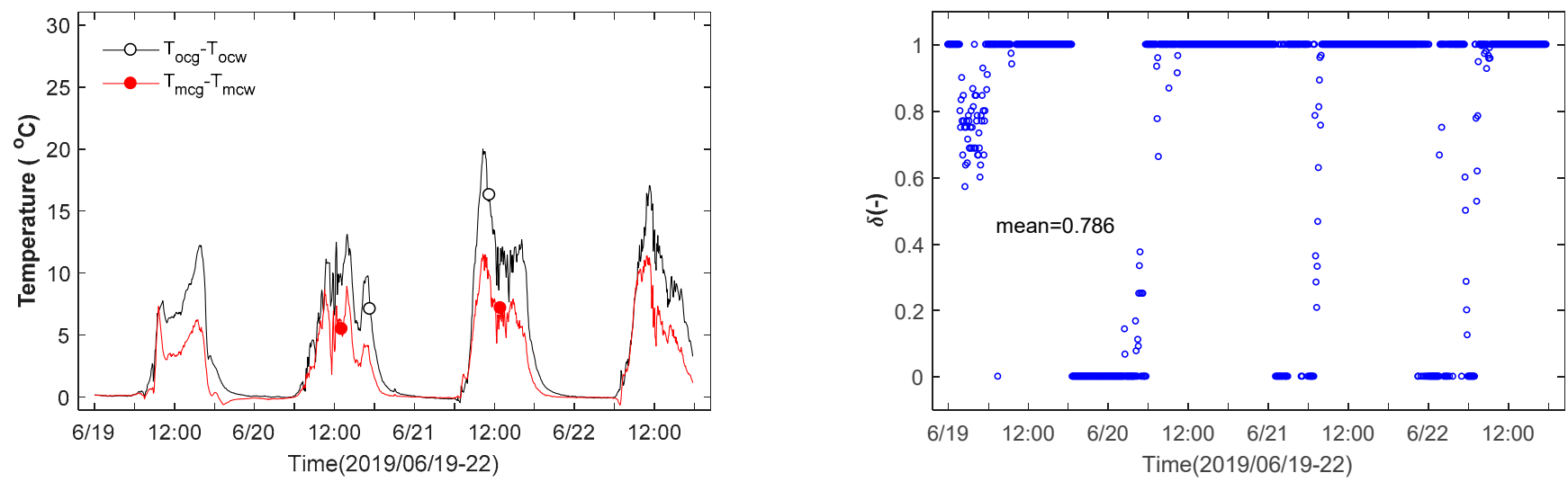

Figure 9. Time serials of $T_{o c g}-T_{o c w}$ and $T_{m c g}-T_{m c w}$ (subscripts $o=$ open square, $m=$ mockup $c=c e n t e r, g=$ gray, and $\mathrm{w}=$ white). 


\section{Discussion}

The results in the above section show similarities and differences to the studies on the $\mathrm{H} / \mathrm{W}(\mathrm{H}=$ building height, $\mathrm{W}=$ street width) aspect ratio, street orientation, and sky view factor on urban microclimates (Table 1). Theoretically, the $\mathrm{H} / \mathrm{W}$ ratio is proportional to the sky view factor of the street. As indicated in some studies [27,29-31], pedestrians feel thermally comfortable in cases of $\mathrm{H} / \mathrm{W}>1.0$, while the region and the local climate act in a secondary role. For instance, Harbich et al. [29] found that a H/W ratio up to 2.0 is enough to improve the thermal comfort in urban area, and that this ratio can be lowered to about 0.5 in cases of shading. This finding is actually coincident with the findings in this study, which indicate that the cross street is not the hottest place, although the solar irradiance on this street is the largest. However, the difference between temperatures in the cross street and the East-West street was very small, except for the time close to the solar noon. This infers that the orientation of the urban street is more important to determining the thermal comfort of an urban canyon than the sky view factor or the $\mathrm{H} / \mathrm{W}$ ratio. According to Toudert et al. [32] and Kruger et al. [26], street orientation dominates the microclimate in an urban area, while the sky view factor plays a secondary role. As shown by the temperature measurements in this study (Figures 4, 6 and 7), pedestrians on South-North streets would be more thermal comfortable than those on East-West streets. While the skin temperature cannot equate to the thermal comfort, which is determined jointly by air temperature, wind, humidity and insolation, thermal comfort decreases with the increase of the skin temperature of the streets. Therefore, the findings in this study are coincident with published articles [33-36].

The findings in this study also confirm the importance of increasing the shady areas in an urban space to improve the thermal comfort of the urban area. As indicated by the temperature contours in the above section, daily solar radiation on a paved street controls the skin temperature. In published articles [35-39], mean radiant temperature is scalar to determine the thermal comfort in an urban area. Without shading, pedestrians will be exposed to sunlight directly, reducing their thermal comfort [40]. When thermal comfort is considered, the shading factor can dilute the importance of other variables such as urban albedo, green ratio, and orientation [23,41]. According to Yuan et al. [38], the optional shading ratio in an urban area is $40 \%$, while a high ratio could suffocate air convection. A summary on the influence of shady areas on the thermal comfort of an urban area can be found in Table 1.

Keeping in mind that this study reports the skin temperature of urban streets while others focus on thermal comfort, one can find that the urban geometry used in this study is very limited and cannot fully represent the cases of other urban morphologies. The building blocks are concrete cubes that do not have hollow spaces. Further works are expected to explore the impact of different canyon geometries, concrete block sizes, and pavement colors (i.e., albedo of paved streets) on the pavement surface temperature. Further studies are also expected to understand the temperature of paved streets over a long time and in different regions. In this study, the experiment time ranged from June 19-24. Within this time spell, the sun was almost right above the experiment location. As a result, the East-West street was exposed to long and strong sunlight during the daytime. At other dates, the solar position would have been different, so the sunlight falling on the paved street would have been different. The temperature of a paved street in an urban canyon would be different accordingly. In addition, this experiment was conducted in a city near the Tropic of Cancer. At other locations (different latitudes), the sunlight falling on the street would be different. However, as the skin temperature is closely correlated to the solar irradiance on the surface, it is believed that the skin temperature shown in this study is similar to the surface temperature of paved streets in real urban areas. 
Table 1. Studies on the H/W aspect ratio, street orientation, and sky view factor on urban microclimates.

\begin{tabular}{|c|c|}
\hline Reference and Location & Results \\
\hline [34] & Thermal comfort of a street is dictated by aspect ratio and street orientation; South-North streets \\
\hline Camaguey, Caba & provide better thermal comfort than East-West ones. \\
\hline [35] & Urban form determines duration of direct sun and mean radiant temperature, with the hottest \\
\hline De Bilt, Netherlands & situation on the East-West street. \\
\hline [33] & The sky view factor of urban streets in the Northern hemisphere is decisive to the heat stress of the \\
\hline Stuttgart, Germany & $\begin{array}{l}\text { urban canyon. A street canyon with an } \mathrm{H} / \mathrm{W} \text {-ratio of at least } 1.5 \text { seems to be the best option to reduce } \\
\text { heat stress. }\end{array}$ \\
\hline [29] & An $\mathrm{H} / \mathrm{W}$ ratio up to 2 increases shade and improves thermal comfort during the daytime more than \\
\hline Campinas, Brazil & $\begin{array}{l}\text { other ratios. Forestry management and green areas increase the shade on façades and pedestrian } \\
\text { routes and enhance the microclimate, particularly for } \mathrm{H} / \mathrm{W} \text { less than } 0.5 \text {. }\end{array}$ \\
\hline [42] & Shaded areas are directly correlated to thermal comfort values, which are depicted by the \\
\hline Rome, Italy & physiologically equivalent temperature. \\
\hline [30] & For all configurations, a South-North street exhibits the best thermal comfort, while the thermal \\
\hline Tunis, Tunisia & comfort of an East-West street is the worst. \\
\hline [31] & South-North streets exhibit good thermal comfort in cases of $\mathrm{H} / \mathrm{W}<1.3$, but in case of $\mathrm{H} / \mathrm{W}>2.0$ \\
\hline Island of Tinos, Greece & show similar thermal conditions to other streets. \\
\hline [36] & North-South and East-West streets are the two extrema, with the highest mean radiant temperature \\
\hline Freiburg, Germany & for North-South and the lowest values for East-West. \\
\hline [37] & The temperature differences between sunlit and shaded urban surfaces reached $20^{\circ} \mathrm{C}$, highlighting \\
\hline Colombo, Sri Lanka & shade as the main strategy for lowering air and radiant temperatures. \\
\hline [25] & \\
\hline $\begin{array}{l}\text { Putrajaya Boulevard, } \\
\text { Malaysia }\end{array}$ & microclimates or heat islands, unless the orientation of the urban street is considered. \\
\hline [26] & The sky view factor correlates strongly to the nocturnal heat island but weakly to the daytime \\
\hline Curitiba, Brazil & temperature, which is dominated by solar irradiance. \\
\hline [32] & South-North streets cause less heat stress in its duration and intensity, whereas East-West streets are \\
\hline Ghardaia, Algeria & thermally uncomfortable for a much longer time. \\
\hline [38] & Increasing the urban green covering around a city up to $40 \%$ improves the urban microclimate, but \\
\hline Osaka, Japan & further increments are compromised of the air convection. \\
\hline [41] & At daytime the shading factor overwhelms the green ratio and surface albedo; at nighttime, \\
\hline Shanghai, China & anthropogenic heat and sky view factors control thermal comfort. \\
\hline [23] & Aspect ratio $\mathrm{W} / \mathrm{H}$ dominates daily net solar-irradiance gains on roads. Reflective cool pavements \\
\hline Osaka, Japan & $\begin{array}{l}\text { should be considered on the North sides of East-West streets and at the centers of North-South } \\
\text { streets. }\end{array}$ \\
\hline [27] & $\mathrm{H} / \mathrm{W}$ ratio and the sky view factor are decisive factors for the observed air temperature in urban \\
\hline Constantine, Algeria & areas. \\
\hline
\end{tabular}

Note: $\mathrm{H}=$ building height, $\mathrm{W}=$ street width.

\section{Conclusions}

This study measured the skin temperature across an urban mockup as an attempt to understand the surface temperature distribution in a real urban canyon. It was found that in summer the East-West street was hotter than the cross street and the South-North street, with a difference of about $3-5^{\circ} \mathrm{C}$ at daytime, and $0.1-1.0^{\circ} \mathrm{C}$ at nighttime, and with $0.1-0.3{ }^{\circ} \mathrm{C}$ daily mean skin temperature. At nighttime, the heat release from buildings can keep the paved street at about $0.2^{\circ} \mathrm{C}$ hotter than paved areas in open spaces. It is also found that a paved street in an open square is hotter than a paved street in an urban mockup due to the shading effect. Our findings substantiate the claim that street orientation controls the skin temperature of an urban street while the sky view factor (or building height and street width) acts only in a secondary role. Increasing the albedo of a paved street in an urban canyon can effectively reduce the skin temperature of the street, although there is some discount (about 0.124). Further studies are also expected to understand the temperature of paved streets over a long time and in different regions. 
Author Contributions: Conceptualization, Y.Q.; methodology, L.W.; formal analysis, P.W.; writing, Y.Z. All authors have read and agreed to the published version of the manuscript.

Funding: Not applicable.

Institutional Review Board Statement: Not applicable.

Informed Consent Statement: Not applicable.

Data Availability Statement: Not applicable.

Acknowledgments: This paper is jointly supported by the National Natural Science Foundation of China (41762022), by the High-level innovation team and outstanding scholar program in Guangxi colleges (granted to Yinghong Qin), by the Science Foundation of Guangxi (Grant nos. 2018GXNSFAA294070, 2018GXNSFDA138009, 2017 GXNSFBA198052), and by the Guilin City Technology Development Project (20170222).

Conflicts of Interest: The authors declare no conflict of interest.

\section{Appendix A}

Figure A1 shows the global horizontal solar irradiation during the experiment, which lasted for four days. Days are attributed to partially sunny days.

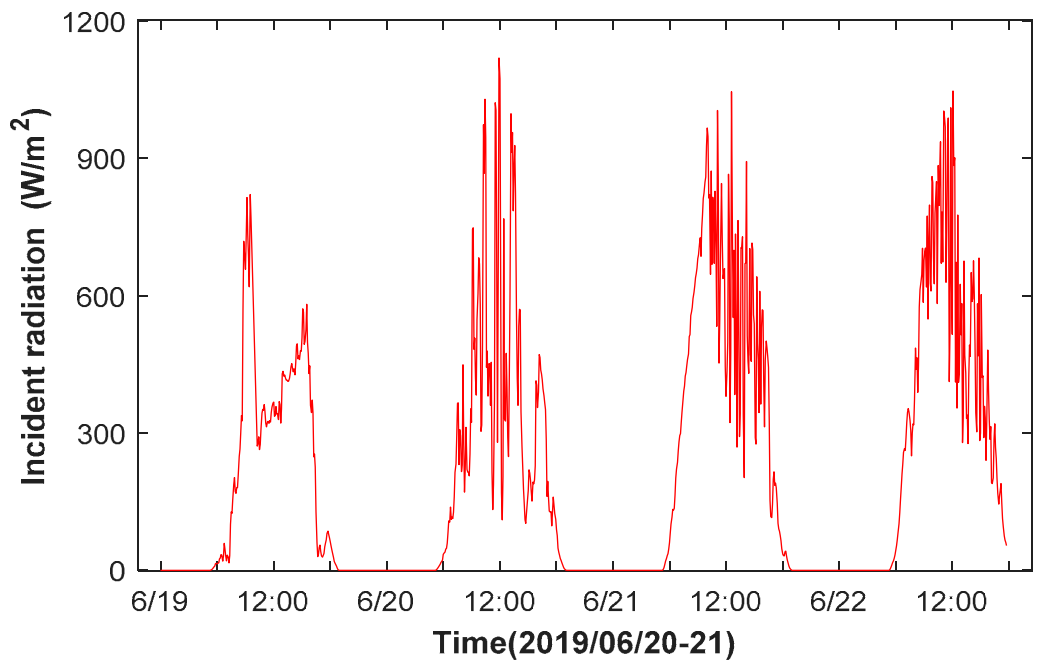

Figure A1. The global horizontal solar irradiance during the experiment.

\section{References}

1. Qin, Y. Urban canyon albedo and its implication on the use of reflective cool pavements. Energy Build. 2015, 96, 86-94. [CrossRef]

2. Aida, M. Urban albedo as a function of the urban structure-A model experiment. Bound. Layer Meteorol. 1982, $23,405-413$. [CrossRef]

3. Chen, J.; Wang, H.; Zhu, H. Analytical approach for evaluating temperature field of thermal modified asphalt pavement and urban heat island effect. Appl. Therm. Eng. 2017, 113, 739-748. [CrossRef]

4. Panão, M.N.O.; Gonçalves, H.P.; Ferrão, P.C. A matrix approach coupled with Monte Carlo techniques for solving the net radiative balance of the urban block. Bound. Layer Meteorol. 2007, 122, 217-241. [CrossRef]

5. Santillán-Soto, N.; Garcia-Cueto, R.; Haro-Rincon, Z.; Ojeda-Benitez, S.; Quintero-Nunez, M.; Velazquez-Limon, N. Radiation balance of urban materials and their thermal impact in semi-desert region: Mexicali, México study case. Atmosphere 2015, 6, 1578-1589. [CrossRef]

6. Parker, J. The Leeds urban heat island and its implications for energy use and thermal comfort. Energy Build. 2021, 235, 110636. [CrossRef]

7. Sharma, R.; Pradhan, L.; Kumari, M.; Bhattacharya, P. Assessing urban heat islands and thermal comfort in Noida City using geospatial technology. Urban Clim. 2021, 35, 100751. [CrossRef]

8. He, B.-J.; Wang, J.; Liu, H.; Ulpiani, G. Localized synergies between heat waves and urban heat islands: Implications on human thermal comfort and urban heat management. Environ. Res. 2021, 193, 110584. [CrossRef] 
9. Qaid, A.; Lamit, H.B.; Ossen, D.R.; Shahminan, R.N.R. Urban heat island and thermal comfort conditions at micro-climate scale in a tropical planned city. Energy Build. 2016, 133, 577-595. [CrossRef]

10. Fahed, J.; Kinab, E.; Ginestet, S.; Adolphe, L. Impact of urban heat island mitigation measures on microclimate and pedestrian comfort in a dense urban district of Lebanon. Sustain. Cities Soc. 2020, 61, 102375. [CrossRef]

11. Ballinas, M.; Barradas, V.L. The Urban Tree as a tool to mitigate the urban heat island in Mexico City: A simple phenomenological model. J. Environ. Qual. 2016, 45, 157-166. [CrossRef]

12. Nichol, J.; Wong, M.S. Modeling urban environmental quality in a tropical city. Landsc. Urban Plan. 2005, 73, 49-58. [CrossRef]

13. Henao, J.J.; Rendón, A.M.; Salazar, J.F. Trade-off between urban heat island mitigation and air quality in urban valleys. Urban Clim. 2020, 31, 100542. [CrossRef]

14. Yuan, J.; Farnham, C.; Emura, K. Inter-building effect and its relation with highly reflective envelopes on building energy use: Case study for cities of Japan. Atmosphere 2017, 8, 211. [CrossRef]

15. Kubilay, A.; Allegrini, J.; Strebel, D.; Zhao, Y.; Derome, D.; Carmeliet, J. Advancement in urban climate modelling at local scale: Urban heat island mitigation and building cooling demand. Atmosphere 2020, 11, 1313. [CrossRef]

16. Shahmohamadi, P.; Che-Ani, A.I.; Etessam, I.; Maulud, K.N.A.; Tawil, N.M. Healthy environment: The need to mitigate urban heat island effects on human health. Procedia Eng. 2011, 20, 61-70. [CrossRef]

17. Heaviside, C.; Macintyre, H.; Vardoulakis, S. The urban heat island: Implications for health in a changing environment. Curr. Environ. Health Rep. 2017, 4, 296-305. [CrossRef]

18. Dong, W.; Liu, Z.; Zhang, L.; Tang, Q.; Liao, H.; Li, X. Assessing heat health risk for sustainability in Beijing's urban heat island. Sustainability 2014, 6, 7334-7357. [CrossRef]

19. Wang, J.; Meng, Q.; Zhang, L.; Zhang, Y.; He, B.-J.; Zheng, S.; Santamouris, M. Impacts of the water absorption capability on the evaporative cooling effect of pervious paving materials. Build. Environ. 2019, 151, 187-197. [CrossRef]

20. Bao, T.; Liu, Z.; Zhang, X.; He, Y. A drainable water-retaining paver block for runoff reduction and evaporation cooling. J. Clean. Prod. 2019, 228, 418-424. [CrossRef]

21. Li, H. Evaluation of Cool Pavement Strategies for Heat Island Mitigation; University of California: Davis, CA, USA, $2012 ;$ p. 387.

22. Cao, X.; Tang, B.; Zhu, H.; Zhang, A. Cooling principle analyses and performance evaluation of heat-reflective coating for asphalt pavement. J. Mater. Civ. Eng. 2011, 23, 1067-1075. [CrossRef]

23. Takebayashi, H.; Moriyama, M. Relationships between the properties of an urban street canyon and its radiant environment: Introduction of appropriate urban heat island mitigation technologies. Solar Energy 2012, 86, 2255-2262. [CrossRef]

24. Touchaei, A.G.; Wang, Y. Characterizing urban heat island in Montreal (Canada)-Effect of urban morphology. Sustain. Cities Soc. 2015, 19, 395-402. [CrossRef]

25. Qaid, A.; Ossen, D.R. Effect of asymmetrical street aspect ratios on microclimates in hot, humid regions. Int. J. Biometeorol. 2015, 59, 657-677. [CrossRef]

26. Krüger, E.L.; Minella, F.O.; Rasia, F. Impact of urban geometry on outdoor thermal comfort and air quality from field measurements in Curitiba, Brazil. Build. Environ. 2011, 46, 621-634. [CrossRef]

27. Bourbia, F.; Boucheriba, F. Impact of street design on urban microclimate for semi arid climate (Constantine). Renew. Energy 2010, 35, 343-347. [CrossRef]

28. Sun, T.; Wang, Z.-H.; Ni, G.-H. Revisiting the hysteresis effect in surface energy budgets. Geophys. Res. Lett. 2013, 40, 1741-1747. [CrossRef]

29. Abreu-Harbich, L.V.; Labaki, L.C.; Matzarakis, A. Thermal bioclimate in idealized urban street canyons in Campinas, Brazil. Theor. Appl. Climatol. 2014, 115, 333-340. [CrossRef]

30. Achour-Younsi, S.; Kharrat, F. Outdoor thermal comfort: Impact of the geometry of an urban street Canyon in a Mediterranean subtropical climate-Case study Tunis, Tunisia. Procedia Soc. Behav. Sci. 2016, 216, 689-700. [CrossRef]

31. Andreou, E. Thermal comfort in outdoor spaces and urban canyon microclimate. Renew. Energy 2013, 55, 182-188. [CrossRef]

32. Ali-Toudert, F; Mayer, H. Numerical study on the effects of aspect ratio and orientation of an urban street canyon on outdoor thermal comfort in hot and dry climate. Build. Environ. 2006, 41, 94-108. [CrossRef]

33. Ketterer, C.; Matzarakis, A. Human-biometeorological assessment of heat stress reduction by replanning measures in Stuttgart, Germany. Landsc. Urban Plan. 2014, 122, 78-88. [CrossRef]

34. Rodríguez Algeciras, J.A.; Gómez Consuegra, L.; Matzarakis, A. Spatial-temporal study on the effects of urban street configurations on human thermal comfort in the world heritage city of Camagüey-Cuba. Build. Environ. 2016, 101, 85-101. [CrossRef]

35. Taleghani, M.; Kleerokoper, L.; Tenpierik, M.; van den Dobbelsteen, A. Outdoor thermal comfort within five different urban forms in The Netherlands. Build. Environ. 2015, 83, 65-78. [CrossRef]

36. Herrmann, J.; Matzarakis, A. Mean radiant temperature in idealised urban canyons-Examples from Freiburg, Germany. Int. J. Biometeorol. 2012, 56, 199-203. [CrossRef]

37. Rohinton, E.; Erik, J. Influence of urban morphology and sea breeze on hot humid microclimate: The case of Colombo, Sri Lanka. Clim. Res. 2006, 30, 189-200.

38. Yuan, J.; Emura, K.; Farnham, C. Is urban albedo or urban green covering more effective for urban microclimate improvement?: A simulation for Osaka. Sustain. Cities Soc. 2017, 32, 78-86. [CrossRef]

39. Salata, F.; Golasi, I.; de Lieto Vollaro, A.; de Lieto Vollaro, R. How high albedo and traditional buildings' materials and vegetation affect the quality of urban microclimate. A case study. Energy Build. 2015, 99, 32-49. [CrossRef] 
40. Watanabe, S.; Ishii, J. Effect of outdoor thermal environment on pedestrians' behavior selecting a shaded area in a humid subtropical region. Build. Environ. 2016, 95, 32-41. [CrossRef]

41. Yang, F.; Lau, S.S.Y.; Qian, F. Urban design to lower summertime outdoor temperatures: An empirical study on high-rise housing in Shanghai. Build. Environ. 2011, 46, 769-785. [CrossRef]

42. Martinelli, L.; Lin, T.-P.; Matzarakis, A. Assessment of the influence of daily shadings pattern on human thermal comfort and attendance in Rome during summer period. Build. Environ. 2015, 92, 30-38. [CrossRef] 